Eur. J. Clin. Chem. Clin. Biochem.

Vol. 30, 1992, pp. 297-300

(C) 1992 Walter de Gruyter \& Co. Berlin $\cdot$ New York

\title{
An Indirect ELISA for Urinary Gonadotropins Using Immobilized Human Menopausal Gonadotropin
}

\author{
By M. I. Khatkhatay ${ }^{1}$, M. P. Desai ${ }^{1}$, G. M. Sankolli ${ }^{2}$ and U. M. Joshi ${ }^{1}$ \\ ${ }^{1}$ Institute for Research in Reproduction (ICMR), Parel, Bombay, India \\ ${ }^{2}$ United Pharmacia House, Cunningham Road, Bangalore, India
}

(Received May 31, 1991/February 28, 1992)

\begin{abstract}
Summary: An indirect ELISA for the estimation of urinary gonadotropins is described. Human menopausal gonadotropin is adsorbed on a microtitre plate, where it serves as an immunosorbent. The residual antigonadotropin antibody is captured by the immunosorbent after reaction with the sample or standard and detected with enzyme-labelled antispecies antibody (antirabbit $\gamma$-globulin-horse radish peroxidase). The assay developed here is rapid and satisfies usual validatory criteria expected from an immunoassay. Moreover, it obviates the need for extraction of samples with acetone, as shown by the close aggreement between the respective lutropin or follitropin concentrations in extracted and unextracted urine samples.
\end{abstract}

\section{Introduction}

The importance of urinary gonadotropin estimations has been amply stressed by us as well as by several other investigators $(1-4)$. The gonadotropin assays described so far require pure hormones for labelling. Procurement of these hormones as well as their labels ( ${ }^{125}$ I and enzymes) is very costly, difficult and time consuming, especially in developing countries. Moreover, labelling usually requires technical skill and prepared labels are not available commercially. However, antisera to follitropin and lutropin are available commercially. We previously described a competitive ELISA for urinary follitropin and lutropin using enzyme-labelled hormone as a marker. We report here a new format for urinary gonadotropin assay which obviates the need for labelled analyte.

This assay utilizes commercially available human menopausal gonadotropin immobilised on solid support as an immunosorbent. After reaction with sample or standard, the residual antigonadotropin antibody is captured by the immunosorbent and detected by antispecies antibody labelled with enzyme i.e. antirabbit $\gamma$-globulin-peroxidase. The enzyme activity on the immunosorbent is inversely proportional to the analyte concentration.

\section{Materials and Methods}

Antisera to human follitropin and human chorionic gonadotropin were raised in rabbits at this Institute using iodination grade human follitropin and injection grade human chorionic gonadotropin (1000 IU ampoule) as immunogens. Human chorionic gonadotropin antiserum showed $100 \%$ cross reactivity with lutropin but very little with follitropin $(0.9 \%)$. Antisera to follitropin showed $0.84 \%$ cross reactivity with lutropin/ human chorionic gonadotropin. First International Reference Preparation for human urinary follitropin and lutropin (IRP 70/45) was obtained from the National Institute for Biological Standards and Controls, U. K. Pergonal (75 IU follitropin and 75 IU lutropin) was purchased from Serono Laboratories and was used for immobilization as well as the secondary standard. Anti-rabbit IgG (whole molecule), peroxidase, $o$-phenylenediamine, bovine serum albumin and Tween-20 were from Sigma Chemicals Co., St. Louis, MO, U. S. A. Polystyrene microtitre plates from Nunc Laboratories, Denmark were used for immobilizing the human menopausal gonadotropin. All other chemicals used were of analytical grade available locally.

Buffers

1) Coating buffer: $50 \mathrm{mmol} / \mathrm{l}$ carbonate - bicarbonate buffer $\mathrm{pH} 9.5$ containing sodium bicarbonate at $1.465 \mathrm{~g} / 1$ and sodium carbonate $0.75 \mathrm{~g} / \mathrm{l}$.

2) Immunoassay buffer: $100 \mathrm{mmol} / \mathrm{l}$ sodium phosphate buffer $\mathrm{pH} 7.2$ containing $14.5 \mathrm{~g} / \mathrm{l}$ of $\mathrm{Na}_{2} \mathrm{HPO}_{4} \cdot 2 \mathrm{H}_{2} \mathrm{O} 3.055 \mathrm{~g} / \mathrm{l}$ $\mathrm{NaH}_{2} \mathrm{PO}_{4} \cdot 2 \mathrm{H}_{2} \mathrm{O}$ and $154 \mathrm{mmol} / \mathrm{l} \mathrm{NaCl}$.

3) Washing solution: $154 \mathrm{mmol} / \mathrm{l} \mathrm{NaCl}$ containing $0.5 \mathrm{ml} / \mathrm{l}$ Tween-20. 


\section{Standards}

Pergonal (75 IU follitropin and 75 IU lutropin) was used as a secondary standard which was calibrated against First International Reference Preparation (IRP 70/45) for human urinary follitropin and lutropin. Pergonal was diluted with phosphate buffered saline $\mathrm{pH} 7.2$ containing $10 \mathrm{~g} / \mathrm{l}$ bovine serum albumin to give a concentration of $3200 \mathrm{IU} / \mathrm{l}$ and $1 \mathrm{ml}$ aliquots of this stock standard were stored at $-20^{\circ} \mathrm{C}$. Working standards for follitropin and lutropin $(160 \mathrm{IU} / 1-2.5 \mathrm{IU} / \mathrm{l})$ were prepared by $1: 20$ dilution in immunoassay buffer of the stock secondary standard to give $160 \mathrm{IU} / 1$, and further standards were made by double dilution.

\section{Collection and processing of urine sample}

A total of 50 early morning urine samples were collected from eight healthy volunteers during different phases of the menstrual cycle. The urine samples were brought to the laboratory on the same day and were preserved with $15 \mathrm{mmol} / \mathrm{l}$ sodium azide at $-20^{\circ} \mathrm{C}$ and analysed within 1 month of collection. Gonadotropins follitropin and lutropin were extracted from all the 50 urine samples by the acetone precipitation method as described by Baghdassarain et al. and reported by us earlier (1). In brief, $1.0 \mathrm{ml}$ of urine was acidified to $\mathrm{pH} 4.5$ with glacial acetic acid; $2 \mathrm{ml}$ acetone were then added and the mixture left overnight at $4{ }^{\circ} \mathrm{C}$. The tubes were centrifuged at $400 \mathrm{~g}$ for 20 min, the supernatant was discarded, and the pellet was dried and used in assay after reconstituting in $1 \mathrm{ml}$ immunoassay buffer.

Immobilisation of human menopausal gonadotropin

The protein content of human menopausal gonadotropin (Pergonal ampoule) was determined. For adsorption, this was diluted in coating buffer to give a protein concentration of 500 $\mathrm{mg} / \mathrm{l}$. An aliquot $(0.2 \mathrm{ml})$ of this solution was dispensed into each well of the polystyrene microtitre plates and left at $4-8^{\circ} \mathrm{C}$ for $16-18 \mathrm{~h}$. The unadsorbed human menopausal gonadotropin was later removed by washing with washing solution.

The assays were carried out as follows:

Tubes containing $0.25 \mathrm{ml}$ of immunoassay buffer, or diluted standards, or urine samples, or acetone extract were incubated at $37^{\circ} \mathrm{C}$ with $0.25 \mathrm{ml}$ of appropriately diluted antiserum to lutropin or follitropin $(1: 20000)$ in immunoassay buffer. After 2 hours incubation, $0.2 \mathrm{ml}$ was transferred in duplicate from each tube to the wells of human menopausal gonadotropincoated plates, and further incubated for $2 \mathrm{~h}$ at $37^{\circ} \mathrm{C}$. The plates were then rinsed several times with washing solution, after which $0.2 \mathrm{ml}$ of antirabbit $\gamma$-globulin-peroxidase conjugate (1:3000 diluted in immunoassay buffer) was added. The plates were further incubated for $1 \mathrm{~h}$ at $37^{\circ} \mathrm{C}$. After rinsing the plates with washing solution several times, enzyme activity was measured as described by Gallati \& Broadbeck (5).
Comparison of the indirect ELISA with comparative ELISA using penicillinase

Gonadotropins follitropin and lutropin were assayed in urine samples diluted 5 times in immunoassay buffer as well as in acetone extracts of the samples, using the solid phase human menopausal gonadotropin assay; they were also assayed in sample extracts using the penicillinase-linked ELISA described earlier (1). The results were then compared using regression line analysis $(6,7)$.

\section{Results}

The data on the validation of the indirect ELISA are given in table 1 and figure 1. The sensitivity of the assay was defined as the smallest amount of standard which differs from zero at the $95 \%$ confidence limit.
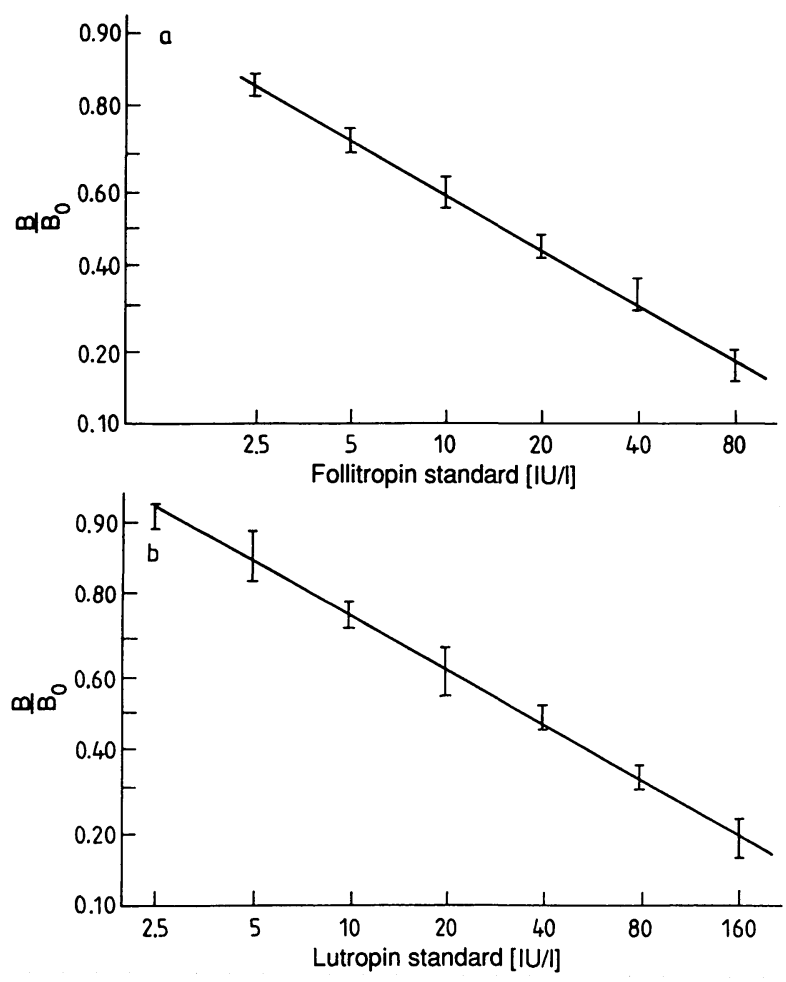

Fig. 1. Composite standard curves of indirect ELISA
a) for follitropin
$y=2.517-2.212 x$
$\mathrm{r}=0.995$
$\mathrm{n}=6$
b) for lutropin
$y=3.958-2.211 x$
$\mathrm{r}=0.993$
$\mathrm{n}=6$

Tab. 1. Data on validation of indirect ELISA

\begin{tabular}{|c|c|c|c|c|c|c|c|}
\hline \multirow[t]{3}{*}{ Hormone } & \multicolumn{2}{|c|}{$\begin{array}{l}\text { Specificity Slope of } \\
\text { dose-response curves }\end{array}$} & \multirow[t]{3}{*}{$\begin{array}{l}\text { Sensitivity } \\
(\mathrm{IU} / \mathrm{l})\end{array}$} & \multicolumn{3}{|c|}{$\begin{array}{l}\text { Recovery of added analyte } \\
\text { (Range) }\end{array}$} & \multirow[t]{3}{*}{$\begin{array}{l}\text { Comparison } \\
\text { with existing assay }\end{array}$} \\
\hline & \multirow[t]{2}{*}{ Standard } & \multirow[t]{2}{*}{ Samples } & & \multirow{2}{*}{$\begin{array}{l}\text { Amount added } \\
\text { to } 1 \text { litre } \\
\text { of urine }\end{array}$} & \multicolumn{2}{|c|}{ Amount recovered $(n=4)$} & \\
\hline & & & & & $\overline{\mathrm{x}} \pm \mathrm{SD}(\mathrm{IU})$ & $\%$ & \\
\hline Follitropin & -2.12 & -2.09 & $2.0-3.0$ & $\begin{array}{l}80 \mathrm{IU} \\
40 \mathrm{IU} \\
20 \mathrm{IU}\end{array}$ & $\begin{array}{l}86 \pm 10 \\
40 \pm 5 \\
16.6 \pm 2\end{array}$ & $\begin{array}{r}108 \\
100 \\
83\end{array}$ & $r=0.943$ \\
\hline Lutropin & -2.211 & -2.100 & $2.5-3.0$ & $\begin{array}{l}80 \mathrm{IU} \\
40 \mathrm{IU} \\
20 \mathrm{IU}\end{array}$ & $\begin{array}{l}80 \pm 7 \\
38 \pm 3 \\
17.4 \pm 3\end{array}$ & $\begin{array}{r}100 \\
95 \\
87\end{array}$ & $\mathrm{r}=0.942$ \\
\hline
\end{tabular}


Sample dilutions of the acetone precipitates and diluted urine samples were analysed to determine the specificity of the assay. A dose response curve parallel to that of the standard curve was obtained, and the slopes obtained for extracted and unextracted samples were similar. A high correlation coefficient between the values obtained by earlier ELISA (1) and the values obtained by present indirect ELISA were observed $(r=0.901$ for follitropin and $r=0.912$ for lutropin). Inter- and intra-assay coefficients of variation $(\mathrm{CV})$ were calculated by incorporating three quality control pools ten times in the same assay and in ten different assays. Their mean value and standard deviation were taken and the CV was calculated. The inter- and intra-assay coefficients of variation for these sample at the different concentrations (for follitropin 10 to $110 \mathrm{IU} / 1$ and for lutropin 10 to 160 IU/l) as determined by the developed ELISA, were within reasonable limits (tab. 2). The recovery of hormones in both the assays was assessed by estimating follitropin and lutropin $(20-80 \mathrm{mIU}$ for both hormones) added to $1 \mathrm{ml}$ urine samples collected from volunteers taking oral contraceptives.

Tab. 2. Precision profile of indirect ELISA

\begin{tabular}{|c|c|c|c|c|c|c|c|}
\hline \multirow[t]{2}{*}{ Hormone } & \multirow[t]{2}{*}{ Pool } & \multicolumn{3}{|c|}{$\begin{array}{l}\text { Inter-assay } \\
(\mathrm{n}=10)\end{array}$} & \multicolumn{3}{|c|}{$\begin{array}{l}\text { Intra-assay } \\
(\mathrm{n}=10)\end{array}$} \\
\hline & & $\begin{array}{l}\overline{\mathrm{x}} \\
(\mathrm{IU} / \mathrm{l})\end{array}$ & S.D. & $\begin{array}{l}\text { CV } \\
(\%)\end{array}$ & $\begin{array}{l}\bar{x} \\
(I U / 1)\end{array}$ & S.D. & $\begin{array}{l}\mathrm{CV} \\
(\%)\end{array}$ \\
\hline $\begin{array}{l}\text { Folli- } \\
\text { tropin }\end{array}$ & $\begin{array}{l}1 \\
2 \\
3\end{array}$ & $\begin{array}{r}13.77 \\
39.92 \\
102.64\end{array}$ & $\begin{array}{l}0.79 \\
2.56 \\
5.04\end{array}$ & $\begin{array}{l}5.81 \\
6.37 \\
4.95\end{array}$ & $\begin{array}{r}14.41 \\
38.56 \\
106.35\end{array}$ & $\begin{array}{l}0.64 \\
1.88 \\
5.85\end{array}$ & $\begin{array}{l}4.4 \\
4.9 \\
5.5\end{array}$ \\
\hline $\begin{array}{l}\text { Lu- } \\
\quad \text { tropin }\end{array}$ & $\begin{array}{l}1 \\
2 \\
3\end{array}$ & $\begin{array}{r}23.95 \\
61.87 \\
100.23\end{array}$ & $\begin{array}{l}1.47 \\
3.92 \\
3.93\end{array}$ & $\begin{array}{l}6.21 \\
6.37 \\
3.93\end{array}$ & $\begin{array}{l}20.45 \\
56.19 \\
95.23\end{array}$ & $\begin{array}{l}1.87 \\
3.44 \\
3.98\end{array}$ & $\begin{array}{l}9.1 \\
6.1 \\
4.2\end{array}$ \\
\hline
\end{tabular}

Further, the fifty urine samples, covering a concentration range of 2.5 to $150 \mathrm{IU} / 1$, were assayed either directly or after acetone precipitation of both the hormones. The results were compared for both assays. There was a good correlation ( $\mathrm{r}=0.971$ for follitropin assay and $r=0.983$ for lutropin assay) between the values obtained for acetone extracts and for direct samples. The regression equations for follitropin and lutropin were $\mathrm{y}=0.969 \mathrm{x}+3.689$ and $\mathrm{y}=1.100 \mathrm{x}$ +2.338 , respectively, where the values (IU/l) for direct urine samples were represented on the $\mathrm{x}$-axis and those for acetone extracts on the y-axis.

\section{Discussion}

The assays reported earlier by us (1) required purification of samples prior to the assay, because a high sample matrix effect was observed when urine samples were used directly. The early assays therefore needed an extra, tedious and time consuming step. In contrast to follitropin and lutropin antisera, which are available commercially, the enzyme-labelled hormones required for these earlier assays are not available commercially and need to be prepared in the laboratory. This may also be a step hindering the wide applicability of the assays, as most clinical laboratories are not able to prepare the conjugates.

The assay described here using immobilized human menopausal gonadotropin overcomes most of the above problems. Firstly, it does not require pure analyte for labelling with enzyme. Instead it makes use of enzyme-labelled second antibody, which is not only easily available from commercial sources but is also less expensive and has a long shelf life. This label can be used as a common reagent for steroid and protein hormone assays based on the immobilized antigen approach $(8,9)$. The developed indirect ELISA is much more sensitive than the reported ELISA based on the same principle (10). Since we did not have access to a specific lutropin antibody, an antibody against human chorionic gonadotropin, which displays $100 \%$ cross-reactivity with human lutropin, was employed. Therefore, the assay can be applied for the diagnosis of endocrine disorders in a paediatric population, as well as in adult males and females after excluding pregnancy.

The indirect assay also eliminates the need to purify the sample, as a highly significant correlation was observed between the analytical values for purified and non-purified samples. The time and cost of purification are therefore saved. For estimating low concentrations of gonadotropins in urine samples (e.g. in samples from prepubertal and hypogonadotrophic children), it may be necessary, however, to purify and concentrate the samples before assay. In addition, it is hoped that antigen-immobilized solid supports will be more stable.

In conclusion, the method described here is a better alternative to the earlier antibody-immobilized competitive ELISAs for urinary gonadotropins. Moreover, this type of assay can be very useful in countries where acquisition of reagents and kits is often difficult and too expensive for routine purposes.

\section{Acknowledgement}

We would like to thank N.I.H., U.S.A. for the supply of the iodination grade hormone follitropin as a part of the Indo U.S. Subcommission Programme. We also thank Dr. V. Raghavan for anti-rabbit $\gamma$-globulin, Mr. D. K. Pardhe for technical assistance and Mrs. Annette Fonseca for typing the manuscript. 


\section{References}

1. Desai, M. P., Khatkhatay, M. I., Sankolli, G. M., Meherji, P. K. \& Joshi, U. M. (1989) Enzyme labelled immunoassay for urinary gonadotropin using penicillinase. Clin. Chim. Acta $184,315-322$.

2. Landy, H., Schneyer, A. L., Whitcomb, R. W. \& Crowley, W. F. (Jr.) (1990) Validation of Highly Specific and Sensitive Radioimmunoassays for Lutropin, Follitropin and Free Alpha Subunit in Unextracted Urine. Clin. Chem. 36, $340-$ 344.

3. Kulin, H. E., Bell, P. M., Santen, R. J. \& Ferber, A. L. (1975) Integration of pulsatile gonadotropin secretion by timed urinary measurements: An accurate and sensitive 3 hour test. J. Clin. Endocrinol. 40, 783-789.

4. Raiti, S. M. B., Light, C. \& Blizzard, R. M. (1969) Urinary follicle stimulating hormone excretion in boys and adult males as measured by radioimmunoassay. J. Clin. Endocrinol. Metab. 29, 884-890.

5. Gallati, H. \& Brodbeck, H. (1982) Peroxidase aus Meerrettich: Kinetische Studien und Optimierung der Aktivitätsbestimmung mit dem Substrat $\mathrm{H}_{2} \mathrm{O}_{2}$ und o-Phenylendiamin. J. Clin. Chem. Clin. Biochem. 20, 221-225.

6. Feldkamp, C. S. \& Smith, S. W. (1987) Practical Guide to Immunoassay Method Evaluation. In: Immunoassays: $A$ Practical Guide (Chan, D. W., ed.) pp. 49-96. Academic Press, Inc. New York.
7. Rodbard, D., Munson, P. J. \& DeLean, A. (1978) A improved curve-fitting, parallelism testing, and optimization for radioligand assay. In: Radioimmunoassay and related procedures in medicine, Vol. 1 International Atomic Energy Agency, Vienna, New York; Unipub. pp. 469-504.

8. Lewis, J. G., Clifford, J. K. \& Elder, P. A. (1990) Monoclonal antibodies to pregnanediol-3-glucuronide: Application to a direct enzyme linked immunosorbent assay of urine. Steroids 55, 314-318.

9. Elder, P. A., Manley, L. \& Lewis, J. G. (1990) Use of Monoclonal Antibody to Estrone-Glucuronide (EG) in an Enzyme Linked Immunosorbent Assay. J. Steroid Biochem. $36,439-443$.

10. Yorde, D. E., Pluta, P. E. \& Sasse, E. A. (1978) Competitive enzyme-linked immunoassay with use of soluble enzyme/ antibody immune complex for labelling. Measurement of human choriogonadotropin, testosterone and Rubella antibody. In: Enzyme Labelled Immunoassay of Hormones and Drugs (Pal, S. B., ed.) pp. 539-372, Walter de Gruyter \& Co., Berlin, New York.

Dr. Usha M. Joshi Deputy Director Institute for Research in Reproduction Parel, Bombay 400012 India 